\title{
Michał Bruliński
}

UNIWERSYTET WARSZAWSKI

\section{Chopin na barykadach, czyli o socrealistycznych narracjach w 1949 roku ${ }^{1}$}

\section{Abstract}

Chopin on Barricades: About the 10oth Anniversary of Chopin's Birth (1949) and Socialist Realism Doctrine in Poland

The main aim of this paper is to examine the discourse on Frédéric Chopin that took place in Poland in 1949, when the 10oth anniversary of his birth coincided with the culmination of the socialist realist propaganda in the field of Polish culture. The discourse, initiated and moderated under effective surveillance of the Polish People's Republic's government, was filled with communist ideology. The authorities aimed at creating a sense of communion in the Polish nation, therefore they undertook numerous actions in the area of cultivating memory of Chopin and reception of his works. The composer was used as a banner under which culture of socialist realism was to be consolidated. Chopin was presented by the narrators in the socialist realist context in various dimensions. "Deep humanism", "truth", "optimism", "sincerity" and "democratic features" of Chopin's music were the crucial notions used by them. Chopin was depicted, among others, as a revolutionist and a prophet of triumph of communism. The oeuvre

1 Niniejszy tekst stanowi obszerne rozwinięcie następującego artykułu: M. Bruliński, Chopin „socrealistyczny”? Rok 1949 w polskim dyskursie muzycznym, [w:] W kręgu kultury PRL. Muzyka - rodzaje i style, red. K. Bittner, D. Skotarczak, Poznań 2017, s. 52-68. 
of Chopin was said to bring together "fraternal countries and nations", Polish People's Republic and Soviet Union, while being simultaneously a crucial element of class conflict. The authorities had a tendency to overemphasize folk roots of his compositions, thus among musical genres composed by Chopin the importance of Mazurka was exaggerated. Other genres without such strong folk connotations, as sonatas, ballades and scherzos, were marginalized in the discourse.

\title{
Keywords
}

socialist realism, socrealism, Fryderyk Chopin, Polish People's Republic, 1949

\author{
Podnoszenie ludowych natchnień do potęgi, \\ przenikającej i ogarniającej Ludzkość całą, podnoszenie \\ ludowego do Ludzkości nie przez stosowanie zewnętrzne \\ i koncesje formalne, ale przez wewnętrzny rozwój \\ dojrzałości, oto jest, co wysłuchać daje się z muzyki \\ Fryderyka jako zaśpiew nasztukę narodową². \\ (Cyprian Kamil Norwid)
}

Mimo iż Norwidowskie intentio auctoris oraz intentio operis z całą pewnością dalekie są od założeń realizmu socjalistycznego, powyższy ustęp - niezwykle chętnie cytowany przy okazji setnej rocznicy śmierci Fryderyka Chopina - wprowadzić może czytelnika w klimat dyskursu muzycznego 1949 roku. Zaskakujący jest fakt, że pośród licznych prac poświęconych najrozmaitszym aspektom twórczości Fryderyka Chopina nie pojawiło się dotychczas żadne wyczerpujące opracowanie dotyczące socrealistycznej opowieści o Chopinie w roku, w którym setna rocznica śmierci genialnego polskiego kompozytora zbiegła się $\mathrm{z}$ apogeum ideologicznej ofensywy na polu kultury w Polsce. Celem niniejszego eseju jest wypełnienie tej luki.

Chopinowskie narracje 1949 roku tropiłem w licznych wydawnictwach jubileuszowych (przeznaczonych dla świetlic, dla dzieci i do-

2 C.K. Norwid, Promethidion, [w:] tenże, Pisma wybrane, t. 2, Poematy, Warszawa 1968, s. 239. 
rosłych, dla osób wykształconych muzycznie i dla amatorów) oraz w prasie (m.in. „Trybuna Ludu”, „Po Prostu”, „Życie Warszawy”, „Ruch Muzyczny” czy „Życie Śpiewacze”). Sięgnąłem także do archiwaliów, przede wszystkim zbiorów Archiwum Akt Nowych (dalej: AAN), źródeł filmowych (Młodość Chopina Aleksandra Forda oraz fragmenty Polskiej Kroniki Filmowej), wreszcie do druków ulotnych, programów koncertów i innych dokumentów życia społecznego. W interdyscyplinarnym szkicu starałem się przedstawić możliwie spójny obraz wszystkich narracyjnych toposów, które odnaleźć można w moderowanym przez władzę ludową dyskursie. Świadomie pominąłem w toku analizy kwestie związane z „polskością” muzyki Fryderyka Chopina, ponieważ poświęcono im już co najmniej kilka rzetelnych opracowań ${ }^{3}$. Nie podjąłem się także przeprowadzenia analizy dzieł muzycznych powstałych z okazji rocznicy (utwory Chopina w transkrypcjach na chóry i orkiestry, pieśni inspirowane muzyką Chopina), ponieważ wymagają one osobnych, szczegółowych badań muzykologicznych. Mam jednak nadzieję, że powyższe wątki doczekają się w nieodległej przyszłości rzetelnych opracowań.

Michał Głowiński zwraca uwagę, że

\begin{abstract}
w obrębie totalitarnej formy fakt się nie liczy, jeśli nie jest opleciony nachalnie podsuwanymi znaczeniami, jeśli nie jest argumentem za jakąś z góry przyjętą tezą ${ }^{4}$. Bardzo często uczestnictwo w praktyce muzycznej staje się w szczególnych momentach historycznych jedynie pretekstem dla różnego rodzaju demonstracji obyczajowych ${ }^{5}$.
\end{abstract}

Takim „szczególnym momentem” był bez wątpienia Rok Chopinowski 1949. Dla władzy ludowej świat dźwięków sam w sobie nie był ważny. Istotne było to, co wynikało z niego w kontekście semantyki. Kluczowy był więc sposób opisywania muzyki i kreowania pamięci o postaciach z muzyką związanych ${ }^{6}$.

3 Ze szczególnym upodobaniem kwestię „polskości” Chopina analizowali Zofia Lissa i Bohdan Pociej. Zob. Z. Lissa, Problem stylu narodowego w muzyce Chopina, Warszawa 1955; B. Pociej, Polskość Chopina, Warszawa 2011.

4 M. Głowiński, Rytuał i demagogia, Warszawa 1992, s. 20.

5 G. Banaszak, Współczesne formy kultury muzycznej, Warszawa 1991, s. 62. Tego typu zjawiskom poświęciła wartościową monografię I. Massaka. Zob. taż, Muzyka jako instrument wpływu politycznego, Łódź 2009.

6 Por. J. Kmita, Kultura jako rzeczywistość myślowa, [w:] Teoria kultury a badania nad zjawiskami artystycznymi, red. T. Kostyrko, Warszawa 1983, s. 16. 
Celem ówcześnie rządzących było kształtowanie nowej socjalistycznej kultury. Przed władzą stało niezwykle trudne zadanie: musiała nie tylko stymulować tworzenie nowych dzieł w pożądanym kształcie, lecz także wpisywać istniejący dorobek kulturowy w socrealistyczne schematy. Elementy kultury, których nie dało się wpisać w te ramy, były zazwyczaj stygmatyzowane, napiętnowane i eliminowane $\mathrm{z}$ jej głównego nurtu. Budując socrealizm, władza musiała także kreować społeczną świadomość artystyczną. Twórczość i osoba Fryderyka Chopina stały się częściami tej skomplikowanej układanki. Chopinowska narracja kształtowana była według przyjętej ogólnie linii polityki kulturalnej państwa.

Postać Chopina rozpoznawana jest jako symbol kultury polskiej, jednak nie oznacza to ani znajomości jego twórczości, ani też żywego zainteresowania jego muzyką. Chopin jest (i był) najczęściej postrzegany przez podręcznikowe stereotypy i symbole patriotyczne, podczas gdy jego muzyka pozostaje wciąż wielu Polakom nieznana ${ }^{7}$. Badanie recepcji twórczości Chopina to zatem w dużej mierze badanie zbiorowej pamięci społecznej.

Zbiorowa pamięć społeczna stanowi jeden z podstawowych składników grupowej identyfikacji, jako że legitymizuje systemy wartości uznawane przez członków grupy8. Jak zauważa Andrzej Szpociński, „W pamięci społecznej zwracanie się ku przeszłości służy łatwo dającym się wytropić praktycznym celom”. Przede wszystkim „używane jest do legitymizacji określonych porządków oraz dostarcza budulca niezbędnego przy konstruowaniu tożsamości zbiorowej"9. Ponadto pamięć społeczna, w której dochodzi do ekspresji grupowych interesów i wartości, ,jest w znacznej mierze wiedzą ułomną, sfałszowaną, mistyfikowaną”. Dlatego też „przyjmuje się niekiedy, że historia jest jedna, pamięci przeszłości zaś tyle, ile grup odwołujących się do niej i zawłaszczających ją na swój użytek"10. Nie zawsze pamięć społeczna musi być historycznym fałszerstwem. Często mamy do czynienia z poetyzacją języka narracji, a więc nasyceniem go symbolami i metaforami. Nadużycia polegają zazwyczaj na selekcji i umiejętnym eksponowaniu odpowiednich faktów.

7 Por. B. Pabjan, Recepcja postaci i twórczości Chopina we współczesnym społeczeństwie polskim, [w:] Chopin w kulturze polskiej, red. M. Gołąb, Wrocław 2009, s. 110.

8 A. Szpociński, Przeszłość jako przedmiot przekazu, Warszawa 2006, s. 28.

9 Tamże, s. 19.

10 Tamże, s. 23. 


\section{Krótki rys faktograficzny}

Przez pierwsze dwa lata po zakończeniu wojny Polacy musieli borykać się z licznymi problemami natury materialnej i egzystencjalnej ${ }^{11}$. W zetknięciu z niemożliwością zaspokojenia podstawowych potrzeb życiowych sztuka schodziła często na dalszy plan, jednak kultura w Polsce Ludowej miała od początku bardzo istotne znaczenie zarówno dla rządzących, jak i rządzonych ${ }^{12}$. Dla władzy, której szczególnie w okresie stalinizmu zależało na konsolidacji i integracji społeczeństwa, kultura stała się polem walki o ukształtowanie nowego człowieka.

W pierwszych latach istnienia Polski Ludowej władza mnożyła instytucje kulturalne, aby od roku 1948 rozpocząć okres synchronizowania ich działań oraz totalnego podporządkowywania ideologii ${ }^{13}$. To wówczas inspirowany wskazówkami z Moskwy aparat władzy w Polsce doszedł do wniosku, że należy skończyć z „daleko posuniętym eklektyzmem, wypływającym z braku wyraźnej koncepcji w realizowaniu zasad realizmu socjalistycznego w sztuce" ${ }^{14}$. Wydział Kultury Komitetu Centralnego Polskiej Zjednoczonej Partii Robotniczej do głównych zadań na rok 1949 zaliczał

popularyzowanie socjalizmu wśród szerokich mas, wychowanie ich w duchu patriotyzmu i internacjonalistycznej solidarności proletariatu oraz uodparnianie mas ludowych wobec burżuazyjnego kosmopolityzmu, wpływu mieszczańskiej ideologii i propagandy wroga ${ }^{15}$.

11 Zob. M. Zaremba, Wielka trwoga. Polska 1944-1947. Ludowa reakcja na kryzys, Kraków 2012.

12 Zob. A. Idzikowska-Czubaj, Rock w PRL-u. O paradoksach wspótistnienia, Poznań 2011, s. 25.

13 Szczegółowe informacje dotyczące struktur instytucji muzycznych w Polsce w badanym okresie odnaleźć można w: AAN, KC PZPR, 237/XVIII/75, Wydział Kultury - Sektor Kulturalno-Oświatowy. Pracownicze Związki Artystyczne, k. 1. Zainteresowanych szczegółami sytuacji, w jakiej znajdowała się polska kultura muzyczna po II wojnie światowej, odsyłam do: K. Baculewski, Współczesność. Część 1: 1939-1974, seria «Historia Muzyki Polskiej», red. S. Sutkowski, t. 7, Warszawa 1996, S. 56.

14 W. Sokorski, Sztuka w walce o socjalizm, Warszawa 1950, s. 156.

15 AAN, KC PZPR, 237/XVIII/17, Wydział Kultury, Sektor Kulturalno-Oświatowy. Centralna Rada Związków Zawodowych, k. 50. 
Podstawowym elementem misji artystów miało być natomiast „tworzenie fundamentów pod budowę kultury i sztuki socjalistycznej”. Nowa sztuka miała za zadanie

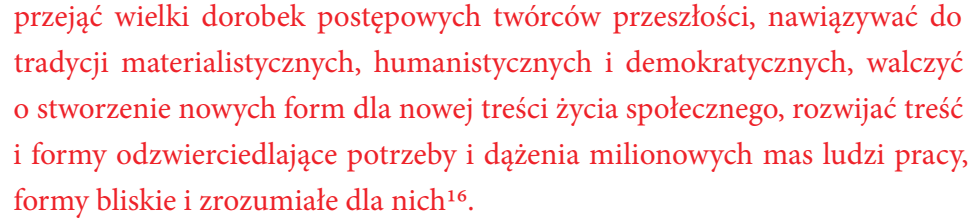

Apogeum ideologicznej ofensywy na polu muzyki przypadło na Zjazd Kompozytorów Polskich w Łagowie, który miał miejsce w dniach 5-8 sierpnia 1949 roku. Po zjeździe łagowskim rozpoczął się finalny etap forsowania na ogromną skalę realizmu socjalistycznego w kulturze muzycznej Polski Ludowej. Zamknięte zostały niezwykle ważne czasopisma - „Ruch Muzyczny” ${ }^{17}$ oraz niezależny „Kwartalnik Muzyczny”. W ich miejsce powołano w 1950 roku „Muzykę", na której kartach zanikły ślady intelektualnej polifonii.

Socrealistycznej sztuce w krajach bloku wschodniego poświęcono już wiele opracowań ${ }^{18}$. Rozwój socrealizmu miał być owocem walki klasowej. Ważny element stanowił narodowy charakter tworzonych dzieł, stale przeciwstawiany „imperialistycznemu, amerykańskiemu kosmopolityzmowi”. Nierozerwalnie powiązany z narodowym charakterem dzieła był folklor, „najdoskonalsza kwintesencja wyobrażeń narodowych w muzyce" ${ }^{19}$. Ponadto każde dzieło sztuki socrealistycznej powinno przybliżać masom robotniczym najnowsze zdobycze kultury wysokiej w przystępnej i zrozumiałej formie.

16 AAN, KC PZPR, 237/XVIII/75, Wydział Kultury, Pracownicze Związki Artystyczne 1948-50, k. 36.

17 Redagowany ówcześnie przez Stefana Kisielewskiego.

18 Zob. np. Polski socrealizm. Antologia publicystyki społeczno-kulturalnej z lat 1948-1957, red. L. Lachowiecki, T. Markiewicz, M. Paczkowski, Warszawa 1988; W. Włodarczyk, Socrealizm. Sztuka polska w latach 1950-1954, Kraków 1991; K. Śliwińska, Socrealizm w PRL i NRD, Poznań 2006; S. Kukurowski, Nie tylko socrealizm. O tzw. literaturze propagandowej, tendencyjnej i zaangażowanej, Wrocław 2005.

19 Z. Lissa, O stylu narodowym, [w:] O społecznych problemach muzyki. Antologia tekstów autorów polskich, red. M. Demska-Trębacz, Warszawa 1994, s. 133. 
Sztukę okresu stalinowskiego cechowały patos, monumentalizm oraz wzniosłość. Owa wznio słość stanowić miała zespolenie w dziele sztuki (i w jego odbiorze) takich jakości jak: piękno, strach, przyjemność, oszołomienie, zachwyt, przerażenie ${ }^{20}$. Socrealistyczne dzieło sztuki nie mogło powstawać w oderwaniu od realiów życia społecznego. Jego zadaniem było „przerobienie i porwanie człowieka”, przy jednoczesnym odrzuceniu „wszelkiej bierności, pesymizmu i apatii”"21. Z tego względu pojęciami wrogimi stały się formalizm i abstrakcja. Należy również pamiętać, że w rozumieniu władzy ludowej realizm socjalistyczny miał być nie tyle estetyczną koncepcją, co „jedyną naukową metodą poznawczą"22.

Jeśli spróbujemy odnieść powyższe postulaty do muzyki, sprawa ulega znacznej komplikacji. Trudno wyodrębnić specyficzne dla muzycznego socrealizmu gatunki, formy czy cechy. Promowana była wprawdzie muzyka wokalna i wokalno-instrumentalna, ponieważ według ideologów kluczowe znaczenie w sztuce muzycznej miał tekst, jednak z oczywistych względów nie można definiować pojęcia socrealizmu w muzyce poprzez wykorzystany aparat wykonawczy. Podobnie rzecz ma się z postulowanymi w bogatej literaturze przedmiotu ogólnymi hasłami, takimi jak: „umiłowanie melodii”, „prostota”, „humanizm”, „rewolucyjny charakter” czy „ludowe inspiracje”. W rezultacie, wobec niemożności pełnego i niebudzącego wątpliwości wcielenia założeń socrealizmu w praktykę muzyczną, niebywałego wprost znaczenia nabierała zewnętrzna narracja obudowująca dzieło muzyczne.

Socrealistyczna burza w świecie kultury zbiegła się z przypadającą na rok 1949 setną rocznicą śmierci Fryderyka Chopina ${ }^{23}$. Z okazji jubileuszu powołano Komitet Honorowy Roku Chopinowskiego ${ }^{24}$ pod przewodnictwem Prezesa Rady Ministrów. W jego skład weszli

20 Zob. Socrealizm? Dyskusja redakcyjna: Michał Bristiger, Andrzej Mencwel, Stefan Morawski, Wojciech Tomasik, Władysław Malinowski, „De Musica” 2002, nr 3.

21 Z przemówienia Prezydenta Rzeczypospolitej Bolesława Bieruta na otwarciu radiostacji we Wrocławiu w dniu 16 listopada 1947 roku, „Przegląd Artystyczny. Pismo Związku Polskich Artystów Plastyków" 1950, nr 2, s. 5.

22 W. Sokorski, dz. cyt., s. 190.

23 Szczegółowy plan wydarzeń towarzyszących obchodom znaleźć można w: Rok Chopinowski w 1949 w Polsce, red. Komitet Wykonawczy Roku Chopinowskiego 1949, Warszawa 1949; M. Fik, Kultura polska po Jałcie. Kronika lat 1944-1981, s. $112-130$.

24 Zob. Rok Chopinowski w 1949 w Polsce, dz. cyt., s. 14. 
członkowie Rządu oraz zaproszeni przez Prezesa Rady Ministrów przedstawiciele sztuki i nauki. W szeregach Komitetu Honorowego Roku Chopinowskiego znaleźli się także przodownicy pracy z Żelazowej Woli i okolic ${ }^{25}$. Stworzono także Komitet Wykonawczy Roku Chopinowskiego, z Ministrem Kultury i Sztuki Stefanem Dybowskim jako przewodniczącym, w skład którego weszli przedstawiciele władz, instytucji artystycznych i naukowych oraz stowarzyszeń i muzycznych związków zawodowych ${ }^{26}$. Do licznych zadań komitetu należały:

opieka nad wydaniem zbiorowym dzieł Fryderyka Chopina, wydawanie prac monograficznych i naukowych związanych z życiem i twórczością Fryderyka Chopina, publikowanie wydawnictw skierowanych do najszerszych warstw ludu pracującego miast i wsi oraz do młodzieży, organizowanie imprez artystycznych w kraju i za granicą, zjazdów, wystaw oraz kongresów, konkursów pianistycznych i kameralnych, zorganizowanie międzynarodowego konkursu na nowelę filmową o Chopinie dla realizacji pełnometrażowego filmu, konkursu na projekt pomnika Chopina w warszawskich Łazienkach oraz konkursu na symbol i plakat Roku Chopinowskiego ${ }^{27}$.

Komitet Wykonawczy był także pośrednio odpowiedzialny za pozostałe wydarzenia przewidziane na Rok Chopinowski ${ }^{28}$. Reasumując, wszelka działalność kulturalna

podejmowana w kraju w czasie od maja 1948 do 31.XII.1949 przez władze, instytucje lub organizacje państwowe, samorządowe czy społeczne w celu uczczenia pamięci Fryderyka Chopina powinna być skoordynowana z działalnością ogólnopolskiego Komitetu Wykonawczego Roku Chopinowskiego i uzyskać jego aprobatę 29.

25 Zob. W komitecie Roku Szopenowskiego zasiadaja przodownicy pracy, „Życie Warszawy" 1949, nr 50, s. 3.

26 W komitecie znaleźli się m.in. Piotr Perkowski (były prezes Związku Kompozytorów Polskich), Zofia Lissa (muzykolog), Witold Rudziński (kompozytor), Zbigniew Drzewiecki, Stanisław Szpinalski i Henryk Sztompka (pianiści). Nie zabrakło jednak „ideologicznych bezpieczników”. Por. AAN, MKiS, sygn. 747, Rok Chopinowski. Uchwaty, zarządzenia, regulaminy, k. 82.

27 Uchwała Rady Ministrów z dnia 20.03.1949 w sprawie „Roku Chopinowskiego”; cyt. za: Rok Chopinowski 1949 w Polsce, dz. cyt., s. 13.

28 Rok Chopinowski 1949 w Polsce, dz. cyt., s. 22.

29 Uchwała Rady Ministrów z dnia 20.03.1949 w sprawie „Roku Chopinowskiego”, [w:] AAN, MKiS, sygn. 747, Departament Twórczości Artystycznej, Wydział Twórczości Muzycznej. Rok Chopinowski, k. 1-2. 
Instytut Fryderyka Chopina odpowiadał natomiast za renowację dworku w Żelazowej Woli, wydawanie dzieł Chopina, powiększanie własnych zbiorów, współorganizację IV Międzynarodowego Konkursu Pianistycznego im. Fryderyka Chopina, utworzenie płytoteki z najlepszymi nagraniami utworów kompozytora, wydanie monograficznych prac o tematyce chopinowskiej oraz projekt jubileuszowych znaczków pocztowych $^{30}$.

Aparat władzy w niezwykle dokładny i metodyczny sposób kontrolował teksty, które ukazywały się drukiem. W samym tylko Ministerstwie Kultury zadanie to spoczywało na kilku wydziałach z różnych departamentów. O poziomie owej kontroli świadczy m.in. ogromna ilość wycinków prasowych w archiwach; niemal wszystkie zostały pieczołowicie opatrzone komentarzami ${ }^{31}$. Ponadto w każdym numerze redagowanego przez Komitet Wykonawczy Roku Chopinowskiego „Biuletynie Roku Chopinowskiego", na podstawie którego tworzone były wszelkie oficjalne informacje medialne związane z obchodami, znaleźć można interesujące analizy artykułów prasowych, często niepozbawione poczucia humoru $^{32}$.

\section{Chopin a muzyka „humanistyczna”}

Według doktryny realizmu socjalistycznego sztuka powinna „wyrwać człowieka z tragicznego osamotnienia", być prawdziwa, szczera, optymistyczna, zrozumiała i „głęboko ludzka” 33 . Przemawiając do człowieka w prosty, zrozumiały sposób - czytelnymi odniesieniami i pozytywnymi emocjami - miała wypełniać go radością i nadzieją. W tym celu forma miała zostać całkowicie podporządkowana owej „głęboko ludzkiej treści”.

30 Szczegółowe projekty Instytutu Fryderyka Chopina na rok 1949 znaleźć można w: M. Idzikowski, Rok Chopinowski w programie Instytutu Fryderyka Chopina, Warszawa 1949.

31 AAN, MKiS, sygn. 762, Departament Twórczości Artystycznej, Wydział Twórczości Muzycznej. Wycinki prasowe; AAN, MKiS, sygn. 747, Departament Twórczości Artystycznej, Wydział Twórczości Muzycznej. Rok Chopinowski, k. 101.

32 AAN, MKiS, sygn. 762, Departament Twórczości Artystycznej, Wydział Twórczości Muzycznej. Wycinki prasowe, k. 38.

33 W. Sokorski, dz. cyt., s. 9. 
Wszystkie te elementy socrealistyczni narratorzy odnajdywali w dziełach Chopina. W eksponowaniu „humanistycznego” aspektu jego twórczości przodowali Rosjanie. Konstantin Igumnow pisał o Chopinie jako „najbardziej realistycznym pośród wszystkich romantyków, szczerym i prawdziwym przeciwniku muzyki beztreściowej, spekulatywnej, abstrakcyjnej" 34 . W podobnym duchu wypowiadał się także Dmitrij Kabalewski ${ }^{35}$. O „,humanistycznej, szczerej prawdzie uczuć, marzeniach o przyszłości, prostocie i sile, ludowym ogniu i podszepniętej przez czyste uczucie, zrodzonej z życia melodii w muzyce Chopina" pisał również Dmitrij Szostakowicz ${ }^{36}$. Oczywiście ustępy traktujące o prawdzie w muzyce Chopina nie mogą być z miejsca dyskwalifikowane jako estetyczne wypaczenia czy też historyczne nadużycia. Decydujące znaczenie miał jednak ideologiczny kontekst, w którym zostały umieszczone. Trudno bowiem uniknąć skojarzeń z polityką w sytuacji, gdy chopinologiczne artykuły sąsiadują w gazecie z tekstami głoszącymi "pochwałę upowszechniania muzyki w Związku Radzieckim” czy też „sukcesy na polu ideologicznej walki o prawdę w sztuce".

„Humanizm” Chopina odnosić miał się przede wszystkim do emocji rzekomo zawartych w dziełach kompozytora. W przemówieniu inaugurującym obchody Roku Chopinowskiego 1949 prezydent Bolesław Bierut stwierdził, że „genialne mistrzostwo kompozytorskie Fryderyka Chopina opiera się na przedziwnej sile uczuć zawartej w jego utworach muzycznych" ${ }^{37}$. Nawet w profesjonalnej prasie muzycznej, która była podatna na wpływy ideologii w stopniu znacznie mniejszym niż prasa codzienna, odnaleźć można ustępy tchnące socrealizmem, traktujące o muzyce Chopina jako „tworzywie ogólnoludzkiej kultury, które przynosi milionom ludzi pracy radość i wytchnienie, uczy kochać piękno i rozbudza drzemiące w masach ludowych bogactwo talentów"38.

34 K. Igumnow, O Chopinie, „Sowietskaja Muzyka” 1949, nr 10; cyt. za: Fryderyk Chopin w oczach Rosjan, red. G. Wiśniewski, Warszawa 2010, s. 321.

35 Wypowiedź D. Kabalewskiego w: Żywa współczesna sztuka, „Literaturna Gazieta” 15.10.1949; cyt. za: Fryderyk Chopin w oczach Rosjan, dz. cyt., s. 313.

36 Wypowiedź D. Szostakowicza w: tamże, s. 309.

37 Przemówienie Prezydenta RP Bolesława Bieruta z okazji inauguracji Roku Chopinowskiego, „Życie Warszawy” 1949, nr 52, s. 1.

38 J. Grosicki, Odkrywamy Chopina Ludowi Polskiemu. Przemówienie v-ceministra Kultury i Sztuki na uroczystym koncercie z okazji 139-ej rocznicy urodzin Fryderyka Chopina, „Ruch Muzyczny” 1949, nr 5-6, s. 2. 


\section{Chopin wobec przyjaciół i wrogów: Rosjanie i Niemcy}

Ważnym aspektem socrealistycznej narracji Roku Chopinowskiego było eksponowanie braterskiej wspólnoty - zarówno wszystkich przedstawicieli proletariatu, jak i narodów polskiego i rosyjskiego. Temu elementowi narracji sprzyjał fakt, że w październiku 1949 roku, zatem w kulminacji obchodów rocznicowych, przypadał Miesiąc Przyjaźni Polsko-Radzieckiej. Warto dodać, że udział w pogłębianiu przyjaźni „bratnich narodów” należał do jednego z rocznicowych obowiązków Instytutu Fryderyka Chopina ${ }^{39}$. Narratorzy roku 1949 utwierdzali odbiorców opowieści o Chopinie w przekonaniu, że jego twórczość „powinna stać się własnością milionów prostych ludzi w Polsce, łącznikiem najszlachetniejszego braterstwa ludów" ${ }^{40}$. Nie pozostało także bez echa, że w ZSRR ,wielkie odbywające się obchody jubileuszowe ku czci Chopina przekształciły się w manifestację braterstwa i przyjaźni polsko-radzieckiej”41. Na łamach „Życia Warszawy” pisano: „dziś imię Chopina i jego twórczość jest symbolem przyjaźni łaczącej naród radziecki z narodem polskim, przyjaźni, która będzie wieczna"42.

Uwielbienie Rosjan dla Chopina podkreślali rosyjscy kompozytorzy. Aleksandr Goldenweiser stwierdził, że „w Rosji od dawna kocha się muzykę Chopina i gra się jej więcej aniżeli utworów jakiegokolwiek innego obcego kompozytora”43. O Chopinie jako „zaufanym przyjacielu rosyjskich serc" pisał również przywoływany wcześniej Kabalewski ${ }^{44}$. Także Szostakowicz zauważał, że „Fryderyk Chopin to jeden z najbardziej ulubionych i najpopularniejszych w naszym narodzie kompozytorów"45. Jurij Szaporin jako powód niebywałej wręcz popularności muzyki Chopina w ZSRR wskazywał „przeniknięcie do mas ludowych szczerej ludowości i wzniosłego humanizmu" mazurków, nokturnów i polonezów polskiego kompozytora ${ }^{46}$.

39 AAN, MKiS, sygn. 740, Instytut Fryderyka Chopina, b.p.

40 Przemówienie Prezydenta RP Bolesława Bieruta..., dz. cyt., s. 1.

41 Twórczość Chopina - sztandarem polskiego ducha wolnościowego, „Życie Warszawy" 1949, nr 287, s. 1.

42 „Życie Warszawy” 1949, nr 288, s. 1.

43 A. Goldenweiser, Geniusz polskiego narodu, „Sowietskaja Kultura” 15.10.1949; cyt. za: Fryderyk Chopin w oczach Rosjan, dz. cyt., s. 317.

44 D. Kabalewski, dz. cyt., s. 313.

45 D. Szostakowicz, dz. cyt., s. 309.

46 J. Szaporin, dz. cyt., s. 6. 
$\mathrm{W}$ podobnym tonie chętnie wypowiadali się rodzimi narratorzy. Zofia Lissa stwierdziła, że w społeczeństwie rosyjskim tradycje chopinowskie są "niezwykle stare i głęboko zakorzenione”, natomiast „radziecka kultura nadała kultowi Chopina pełniejszy wymiar”, wzbogacając niejako „chopinowskie koło hermeneutyczne” 4 . Premier Józef Cyrankiewicz mówił natomiast o głębokiej radości, jaką napełnia go „fakt wspaniałych sukcesów na Konkursie [Chopinowskim] artystów kraju zwycięskiego socjalizmu i zwycięskiej socjalistycznej kultury artystów Związku Radzieckiego" ${ }^{48}$. Niewątpliwie Chopin był Rosjanom bliski, i to z co najmniej kilku powodów, przy czym tylko część z nich miała związek z realizmem socjalistycznym. Jednak w narracji władzy ludowej wszelkie przejawy tej bliskości polskiego kompozytora stawały się „nićmi łączącymi kultury bratnich narodów”" ${ }^{49}$, były zatem wykorzystywane w służbie ideologii.

Fundamenty historycyzującej narracji, która dotyczyła relacji samego Chopina z władzami carskimi, były dość chwiejne. Autorzy często gubili się, próbując zachować ideologiczną poprawność ${ }^{50}$. Wątpliwości nie występowały natomiast $\mathrm{w}$ przypadku opowieści o historycznym braterstwie między polskim a rosyjskim ludem. Pojawiające się w tym kontekście zamienne operowanie przymiotnikami „rosyjski” i „radziecki" przez autorów wielu jubileuszowych tekstów, które niejednego czytelnika wprawia zapewne w zasadną konfuzję, mogło być zabiegiem celowym. Umożliwiało mianowicie wygodne manipulowanie historyczną prawdą i wykorzystywanie „rosyjskości” lub „radzieckości” w pożądany ideologicznie sposób. Warto dodać, że w umysłach rówieśników Chopina idea braterstwa narodów była obecna i żywa, jednak wpisywanie owej idei w kontekst ideologiczno-polityczny pozbawia narrację cech obiektywizmu.

W czarno-białym świecie realizmu socjalistycznego nie mogło zabraknąć jasno określonego wroga. W narracji władzy ludowej stały się nim nazistowskie Niemcy. Należy pamiętać, że w 1949 roku wciąż trwał spór o zachodnią granicę Polski, dlatego też „kwestia niemiecka” była bardzo aktualna. Przekonywające połączenie wciąż żywej w Roku

47 Z. Lissa, Chopin w ZSRR, „Trybuna Ludu” 1949, nr 50, s. 4.

48 Fragment przemówienia premiera Józefa Cyrankiewicza w: Twórczość Chopina wyrosła $z$ ludu i jest siła w walce o wolność ludów, „Życie Warszawy” 1949, nr 287, s. 1.

49 Tamże.

50 Zob. Z. Lissa, Fryderyk Szopen, Moskwa 1944, s. 19. 
Chopinowskim sprawy potępienia nazistów z osobą wybitnego polskiego romantyka wymagało odpowiedniej podbudowy historycznej. Toteż „wątek niemiecki” w socrealistycznej opowieści o Chopinie budowano na fundamencie rzekomej niechęci polskiego kompozytora do „obcej i dalekiej" twórczości klasyków wiedeńskich ${ }^{51}$, która nie znajduje zresztą żadnego potwierdzenia w źródłach z epoki.

Dobrym przykładem połączenia narracji antyniemieckiej z osadzoną w biografii twórcy narracją o Chopinie jest Młodość Chopina Aleksandra Forda - pierwszy polski film o tym kompozytorze. Jest to monumentalna produkcja państwowa przygotowana w ramach Roku Chopinowskiego 1949. Wspomniany już wcześniej konkurs na scenariusz noweli filmowej o Chopinie ogłoszony został przez Państwowe Przedsiębiorstwo „Film Polski” w maju 1948 roku. Film zrealizowano ostatecznie w 1951, a na ekrany wszedł w maju 1952 roku $^{52}$. W Młodości Chopina główny bohater natychmiast po wyjeździe do Wiednia - ukazanego jako wroga wszelkim rewolucyjnym tendencjom siedziba skrajnych reakcjonistów - zaczyna podupadać na zdrowiu. Warto podkreślić, że sam fakt złego samopoczucia Chopina na ziemi niemieckiej znajduje uzasadnienie faktograficzne, choć na fundamencie prawdy historycznej Aleksander Ford stworzył obraz zideologizowany, daleki od historycznej rekonstrukcji. Drugiego dnia świąt Bożego Narodzenia 1830 roku kompozytor, odczuwając głęboką potrzebę uczestnictwa w powstaniu listopadowym, pisał do Jana Matuszyńskiego: „Wszystkie obiady, wieczory, koncerta, tańce, których mam po uszy, nudzą mię: tak mi tu smętno, głucho, ponuro" 53 . Z listów Chopina wiemy również, że we wściekłość wprawiły go posłyszane w wiedeńskiej traktierni komentarze: „Drogi Bóg popełnił błąd, stwarzając Polaków”" ${ }^{4}$.

Poszukując w socrealistycznym dyskursie o Chopinie fragmentów dotyczących Niemców, napotkać można jednak przede wszystkim odniesienia do Niemiec hitlerowskich. Muzyka Chopina stale przeciwstawiana była „brutalnej pięści hitleryzmu, faszystowskiej nawałnicy oraz żelaznej niemieckiej stopie, która przeszła przez Żelazową

51 J. Broszkiewicz, Opowieść o Chopinie, Łódź 1949, s. 34.

52 T. Lubelski, Chopin w trzech biograficznych filmach fabularnych polskich reżyserów, [w:] Chopin w kulturze polskiej, dz. cyt., s. 256.

53 Korespondencja Fryderyka Chopina, red. B. Sydow, t. 1, Warszawa 1955, s. 165.

54 „Der liebe Gott hat einen Fehler gemacht, dass er die Polen geschaffen hat”. Zob. tamże. 
Wolę"55. Wątek hitlerowskiej okupacji służył w socrealistycznym dyskursie jako fundament opowieści o narodowym charakterze twórczości Chopina. Dobrym tego przykładem jest jedno z przemówień Józefa Cyrankiewicza, w którym premier wskazywał, że „rocznice największych geniuszów sztuki polskiej [...] tak istotnie i tak organicznie związane są z rozgromieniem faszyzmu" 56 .

Oczywiście nie można kwestionować winy nazistowskich Niemiec za zniszczenie wielu bezcennych zabytków kultury polskiej. Warto jednak zwrócić uwagę na fakt, że tak znaczne nagromadzenie w dyskursie chopinowskim skrajnie pejoratywnych i nacechowanych emocjonalnie epitetów, dotyczących zagadnienia w żaden sposób niezwiązanego bezpośrednio z twórczością polskiego kompozytora, z pewnością miało na celu nieco więcej niż tylko przypomnienie czytelnikowi tragicznych wydarzeń sprzed zaledwie kilku lat.

\section{Chopin - przyjaciel ludu}

W jednej z chopinowskich opowieści dla dzieci Jerzy Broszkiewicz wskazywał, że „Pan Mikołaj Chopin odbył w swym życiu istotnie bardzo daleką drogę: z chłopskiej, nędznej chaty do oficyn pałacu Krasińskich" ${ }^{57}$. Ojciec kompozytora staje się - nie tylko u Broszkiewicza - niezwykle aktualnym symbolem awansu społecznego warstwy ludowej. Z kolei Zofia Lissa przedstawiła sielankowy obraz, który idealnie wpisuje się w konwencję quasi-hagiograficzną. W jej opowieści Fryderyka Chopina „wydała na świat polska wieś”; narodził się on przy akompaniamencie muzyki ludowej, nieopodal chłopskich chat, „w sercu kultury ludowej, którą miał później tak wspaniale rozsławić" ${ }^{58}$. Nie przypadkiem już w dwóch pierwszych,

55 Z. Lissa, Chopin. Materiały do użytku świetlic, Warszawa 1949, s. 29. Zob. również fragment przemówienia premiera Józefa Cyrankiewicza w artykule: Rok Chopinowski. Ku czci największego geniusza muzyki polskiej, „Kurier Polski” 1948, nr 274, s. 1 oraz tekst Żelazowa Wola czeka na gości, „Polska Zbrojna” 1948, nr 474, s. 6 .

56 AAN, MKiS, sygn. 742, Przemówienie Premiera Cyrankiewicza na wręczeniu nagród IV Międzynarodowego Konkursu Pianistycznego im. Fryderyka Chopina $w$ Warszawie, k. 64.

57 J. Broszkiewicz, dz. cyt., s. 16.

58 Z. Lissa, Chopin. Materiały..., dz. cyt., s. 9. 
niezwykle krótkich akapitach broszury Fryderyk Szopen, słowo „wies”" w różnych formach pojawia się aż sześć razy ${ }^{59}$. Lissa próbowała przekonać czytelników, że narodowy charakter muzyki Chopina wynika $\mathrm{z}$ „głębokiego przeniknięcia jego stylu kompozytorskiego muzyką ludową"60. W podobnych kontekstach umieszczał Chopina Jarosław Iwaszkiewicz:

Należy wierzyć różnorodnym legendom, które opowiadają, że Chopin od najwcześniejszego dzieciństwa szukał kontaktu z ubogim ludem polskim, że [...] słuchał smutnych śpiewów pańszczyźnianego jeszcze chłopa - aby potem ten smutek doli chłopskiej w swoich mazurkach i piosenkach wyśpiewać ${ }^{61}$.

Pragnę uczynić w tym miejscu zastrzeżenie, że o ile polski kompozytor niewątpliwie czerpał inspirację z twórczości ludowej, o tyle kreowanie Chopina na „najbliższego przyjaciela ludu” z historycznego punktu widzenia jest znacznym nadużyciem. Wynika to jasno choćby z listów kompozytora ${ }^{62}$. Chopin jako pianista nie przepadał za wypełnionymi po brzegi gminem salami; zdecydowanie wolał siadać do fortepianu w kameralnych arystokratycznych salonach, pośród najbliższych mu osób. Sama sztuka Chopina posiadała wyraźne znamię „elitarności”, toteż stawianie postaci polskiego kompozytora na froncie walki o upowszechnienie muzyki wśród ludu było ze strony władzy zabiegiem tyleż zręcznym, co nijak mającym się do prawdy historycznej.

W socrealistycznej narracji chopinowskiej polska wieś zajmowała szczególne miejsce. Stanowić miała krynicę inspiracji i źródło, które pozwalało przezwyciężyć „drżącemu ze wzruszenia” kompozytorowi i pianiście wszelkie kryzysy twórcze ${ }^{63}$. Miał on rzekomo twierdzić, że „ratunku można szukać tylko [...] w bliskości ludu”64. Rocznicowi narratorzy musieli znaleźć analogiczny „czynnik katartyczny”, który już po opuszczeniu ojczyzny umożliwiałby Chopinowi oczyszczenie umysłu, podreperowanie zdrowia i czerpanie inspiracji. Takim czynnikiem stały się pobyty w Nohant, które według Broszkiewicza miało

59 Taż, Fryderyk Szopen, dz. cyt., s. 3.

60 Tamże.

61 J. Iwaszkiewicz, Chopin, Warszawa 1949, s. 12.

62 Zob. np. List Fryderyka Chopina do Tytusa Woyciechowskiego, 25.12.1831, [w:] Korespondencja Fryderyka Chopina..., dz. cyt., s. 120.

63 J. Broszkiewicz, dz. cyt., s. 45.

64 Tamże, s. 120. 
przypominać kompozytorowi Mazowsze, dzięki czemu powstały tam jego „najpiękniejsze, najważniejsze dzieła”65.

Za pomocą postaci i twórczości Chopina dokonywano nobilitacji kultury ludowej, która w sztuce realizmu socjalistycznego zajmowała najważniejsze miejsce. To „melodie dalekiej ojczyzny, zawodzenia pastuszych fujarek, dziarskie przytupywania taneczników w mazurach i oberkach" nadawały muzyce Chopina "najczystszy wyraz uczuć narodu”66. Właśnie z „muzyki ludu czerpać miał natchnienie dla swej pracy twórczej, w niej widział źródło najczystsze swej fantazji kompozytorskiej" ${ }^{7}$. Cytowany ustęp - choć umieszczony jest w zideologizowanym kontekście - do pewnego stopnia zgodny jest z faktycznym stanem rzeczy, co potwierdzają kilkukrotne wzmianki w korespodencji Chopina o jego epaces imaginaires.

W służbie ideologii został wykorzystany także chopinowski mazurek. To właśnie ten gatunek uznany został za najbardziej „demokratyczny" w całej twórczości Chopina ${ }^{68}$. We wszystkich projektach audycji świetlicowych proponowanych przez Zofię Lissę w broszurce Chopin. Materiały do użytku świetlic na około dziewięć utworów prezentowanych w czasie jednego koncertu zawsze pojawiały się minimum trzy mazurki69. Jest to zrozumiałe ze względu na fakt, że mazurek cechuje się prostą formą, wyraźnymi inspiracjami ludowymi i zazwyczaj dużym stopniem klarowności harmoniczno-fakturalnej, co czyni go gatunkiem stosunkowo łatwym w odbiorze. W apologii Chopinowskiego mazurka socrealistyczni narratorzy szli jednak znacznie dalej: z cytowanej już publikacji Jerzego Broszkiewicza dowiadujemy się, że Chopin nie skomponował żadnej opery, ponieważ „odrzucił jej patetyczną i napuszoną formę" właśnie na rzecz prostego, ludowego mazurka ${ }^{70}$. Polski kompozytor, dywagując na temat rozmaitych gatunków muzycznych, miał według Broszkiewicza powiedzieć o mazurku: „to jest moja narodowa sztuka. Nie aria dla króla w tekturowej koronie, tylko pieśń ży-

65 Tamże, s. 45.

66 J. Iwaszkiewicz, dz. cyt., s. 56.

67 Z. Lissa, Fryderyk Szopen, dz. cyt., s. 22.

68 B. Asafjew, Chopin w wykonaniu rosyjskich wirtuozów, „Sowietskaja Muzyka” 1947, nr 3, s. 7.

69 Z. Lissa, Chopin. Materiaty..., dz. cyt., s. 47.

70 J. Broszkiewicz, dz. cyt., s. 144. Prawdą jest, że Chopin opery nie napisał, jednak był to owoc konsekwentnej postawy twórczej, uwarunkowany estetycznymi preferencjami, bynajmniej nie wrogością kompozytora w stosunku do tego gatunku. 
wego ludu, mojego narodu!"71. Autor Opowieści o Chopinie zauważył, że to właśnie od mazurków, które ukazały się w $1832 \mathrm{roku}^{72}$, „datuje się początek tryumalnego pochodu Chopinowskich dzieł przez Europę"73. W nieco bardziej subtelny sposób o mazurkach pisał Iwaszkiewicz, określając je jako „niewyczerpaną skarbnicę prawdziwych arcydzieł”, w której polski kompozytor „zawarł całe bogactwo swej duszy”74. Należy podkreślić, że Iwaszkiewiczowska biografia Chopina to jedna $\mathrm{z}$ najlepszych pozycji tego typu aż po dziś dzień. Iwaszkiewicz dał się jednak uwikłać w skomplikowany flirt z ideologią, i choć nie dopuszczał się historycznych manipulacji czy przeinaczeń, można odnaleźć w jego dziele - szczególnie w wydaniu z 1949 roku - ustępy zabarwione ideologicznie.

Kompleksowo zagadnienie „ludowości” potraktował Aleksander Ford we wspominanej już Młodości Chopina. Film rozpoczyna scena, która przedstawia grzejących się przy ognisku wieśniaków. Stosowane przez Forda efekty montażowe budują kolejne warstwy zideologizowanych znaczeń: płynne przejście od ogniska, przy którym grzeją się chłopi, do salonu, w którym koncertuje Chopin, może sugerować, że to właśnie w jego grze odbija się pieśń pokrzywdzonego ludu. Podobnie jak u Jerzego Broszkiewicza, w scenariuszu Młodości Chopina poruszona została kwestia Mikołaja Chopina i jego „wspaniałego awansu z ludu do profesury"75. Kilka kadrów z filmu można uznać za mistrzostwo socrealistycznej kinematografii. W jednym z ujęć Chopin wskazuje drogę zagubionym chłopom udającym się na Marymont w poszukiwaniu pracy w fabryce sukna. Postać Chopina w kadrze góruje nad biednymi chłopami, młody wirtuoz wskazuje im drogę niczym pomnik. Jest to bardzo czytelny sygnał dla odbiorcy: to Chopin wyznacza kierunek rozwoju kultury ludowej. W kolejnej scenie młody geniusz broni chłopa przed batem jednego z pachołków hrabiego Branickiego. Ten jednak przypomina twórcy mazurków, że jest synem guwernera, zatem jako niearystokrata nie może kwestionować rozkazów hrabiego. $\mathrm{W}$ tym momencie Chopin dobrowolnie staje w tym samym szeregu co bity chłop. W obrazie Forda zatem polski kompozytor i pianista

71 Tamże.

72 Broszkiewiczowi mogło chodzić o op. 6, 7 lub 17.

73 J. Broszkiewicz, dz. cyt., s. 108.

74 J. Iwaszkiewicz, dz. cyt., s. 85.

75 J. Broszkiewicz, dz. cyt., s. 16. 
jest nie tylko obrońcą uciśnionego ludu, ale wręcz jego przedstawicielem. Podobne wyobrażenie przedstawił wielokrotnie cytowany Józef Broszkiewicz, który w kwestii „bratania Chopina z ludem” posunął się bodaj najdalej z autorów analizowanych przeze mnie tekstów ${ }^{76}$.

W kolejnej scenie Młodości Chopina główny bohater przyjeżdża na wieś małym szlacheckim dyliżansem. Podczas deszczowej nocy dyliżans gubi koło, a Chopin za radą woźnicy kryje się na noc w pobliskiej chłopskiej chacie ${ }^{77}$. Rankiem w pełnym słońcu chłopi podwożą kompozytora powozem, radośnie śpiewając ludowe pieśni. Po nocy spędzonej przez Chopina wśród chłopów w obrazie Forda następuje więc całkowita przemiana sposobu, w jaki ukazywana jest przestrzeń. Mówiąc metaforycznie, scena ta sugeruje, że nie tylko Chopin wzniósł kulturę ludową na wyżyny artyzmu, ale także kultura ludowa pomogła mu wznieść się z deszczowej nocy w ciasnym, arystokratycznym dyliżansie do otwartego, słonecznego nieba podziwianego z ogromnego chłopskiego wozu, na którym dla każdego znajdzie się miejsce.

W obrazie Forda - podobnie jak w wielu innych opowieściach rocznicowych - Chopin najlepiej czuje się wśród ludu. Ponad wytworne rozrywki salonów przedkłada zabawę przy wiejskiej muzyce i wycieczki do lasu, a w przezwyciężeniu wszelkich kryzysów pomaga mu obcowanie z „pieśnią gminną” i jej twórcami. Szczególnie wymowna jest scena w tawernie, gdzie Stefan Witwicki prosi poznanego właśnie młodego wirtuoza o skomponowanie melodii do kilku pieśni. Już kilka minut później cała karczma wspólnie śpiewa Hulankę, a muzyka Chopina płynnie przechodzi w ludowy oberek. Przeciwieństwem tej sielankowej scenerii jest u Forda ponura, burżuazyjna miejska kawiarnia, ukazana jako przestrzeń wieloaspektowego konfliktu. W tym kontekście zupełnie naturalny zdaje się fakt, że bohater Młodości Chopina poza kilkoma wyjątkami (fragment Sonaty h-moll, Etiudy c-moll "Rewolucyjnej" op. 10 i Etiudy a-moll op. 25) gra na fortepianie przede wszystkim mazurki.

Kolejnym interesującym zabiegiem retorycznym stosowanym przez socrealistycznych narratorów było uzasadnianie geniuszu Chopina rzekomym popytem na jego twórczość wśród mas ludowych. Dzieła polskiego kompozytora w Związku Radzieckim miały rozchodzić się „W milionach egzemplarzy”, co nie powinno dziwić, skoro „to prze-

76 Tamże, s. 45.

77 Epizod ten do pewnego stopnia nawiązuje do prawdziwych wydarzeń z życia kompozytora. Por. List Fryderyka Chopina do rodziny, 1.o8.1829, Korespondencja Fryderyka Chopina, dz. cyt., t. 1, s. 88. 
cież masy ludowe stanowią grupę najbardziej chłonnych i wrażliwych odbiorców sztuki, którzy swym nieomylnym instynktem wyczuwają wartość dzieła”78. „Genialność Chopina” była przedstawiana w moderowanej przez władzę ludową narracji jako wymowne świadectwo faktu, iż „twórczość naprawdę wielka wyrasta z tego, co ludowe, i dzięki temu staje się dobrem ogólnoludzkim"79.

Wielowątkowa narracja osnuta wokół twórczości i osoby Fryderyka Chopina była również dostosowana do potrzeb najmłodszych odbiorców. W inscenizowanych opowieściach dla dzieci Mały Chopin pióra Janiny Skowrońskiej ${ }^{80}$ ludowy charakter twórczości kompozytora urasta do aspektu głównego, przytłaczającego wszystkie inne elementy narracji ${ }^{81}$. Młody Fryderyk z tekstu Skowrońskiej kieruje do parobka Wojtka następujące słowa: ,jak słyszę wasze pieśni, to mi wtedy dobrze"82. Należy wszakże podkreślić, że o „zasłuchaniu” Chopina w pieśniach prostego ludu i jego entuzjazmie wobec nich można było przeczytać nie tylko w opowiadaniach dla dzieci ${ }^{83}$.

Oczywiście samo zainteresowanie mazurkami Chopina i inspiracjami ludowymi w jego twórczości podczas obchodów rocznicowych nie implikuje powiązań $\mathrm{z}$ realizmem socjalistycznym. Jednak fakt, że mazurek przedstawiany był jako forma o największym znaczeniu w twórczości Chopina, że poświęcono mu nieproporcjonalnie dużo uwagi w stosunku do innych gatunków oraz że wokół ludowego aspektu twórczości Fryderyka Chopina tworzono aurę nieomal mistyczną, nie pozostawia wątpliwości co do jednoznacznie ideologicznej motywacji. Warto także zauważyć, iż niezwykły wprost wysiłek włożony w 1949 roku w promowanie ludowego aspektu twórczości Chopina słabł wraz z kolejnymi jubileuszami oraz stopniowym upadkiem doktryny realizmu socjalistycznego.

78 Żywe wydanie dzieł Fryderyka Chopina. Program czternastu koncertów obejmujących cała twórczość Fryderyka Chopina, red. Komitet Wykonawczy Roku Chopinowskiego 1949, Warszawa 1949, s. 7.

79 Przemówienie Prezydenta RP Bolestawa Bieruta..., dz. cyt., s. 1. W oryginale cały cytowany fragment jest pogrubiony.

80 J. Skowrońska, Mały Chopin. Inscenizowane opowieści z cyklu „Teatr dzieci z podwórka", Warszawa 1949.

81 Tamże, s. 26.

82 Tamże, s. 28.

83 Zob. np. J. Jasieński, Ludowość w muzyce Fryderyka Chopina, „Trybuna Ludu” 1949, nr 50, s. 4. 


\section{Socrealistyczna walka klas}

Doktrynę realizmu socjalistycznego cechował wybitnie dialektyczny charakter. Sztuka socrealistyczna postrzegana była jako walka nowego ze starym, proletariatu z burżuazją, postępu ze wszetecznictwem ${ }^{84}$ walka, która „trwa wszędzie, na każdym odcinku życia”" ${ }^{5}$. Według Włodzimierza Sokorskiego „sztuka ludowa [...] ukształtowała się jako antyteza szlacheckiej, dworskiej kultury, sięgając tym samym korzeniami swymi okresu pańszczyźnianej pracy najszerszych mas chłopskich"86. Proletariat przeciwstawiał on również mieszczaństwu:

psychika robotnika, klasowo i politycznie przeciwstawna psychice mieszczaństwa w ocenach moralnych, estetycznych i kulturalnych, różni się od mentalności mieszczańskiej przede wszystkim zdrową, twórczą postawą wobec zagadnień walki o nowy ustrój, o nowy stosunek do własnego życia ${ }^{87}$.

Z takiej perspektywy niezwykle łatwo wpisywać wszelkie działania w obszarze kultury w kontekst dialektyki marksistowskiej. Jeśli chodzi o narrację chopinowską, rzutowało to nawet na ortografię - usilne spolszczanie nazwiska kompozytora wynikało zapewne z obawy, że prosty rolnik czy robotnik, który z twórczością Chopina zetknął się po raz pierwszy przy okazji setnej rocznicy śmierci genialnego kompozytora, mógł odczuć zgrzyt pomiędzy usilnie eksponowaną "polskością” twórcy mazurków a jego niepolskim nazwiskiem, nasuwającym skojarzenia z zachodnim „kosmopolityzmem"s8.

$\mathrm{W}$ rocznicowych przemówieniach prezydent Bierut wykluczał z narodowej wspólnoty „szlachtę i elitę burżuazyjną", wpisując jednocześnie wszystkie obchody Roku Chopinowskiego 1949 w kontekst walki klas. Podkreślał, że po raz pierwszy w historii „wspaniały dorobek polskiej kultury narodowej” stał się „,własnością mas pracujących”" ${ }^{89}$. W podobnym tonie wypowiadał się premier Cyrankiewicz:

84 Por. W. Sokorski, dz. cyt., s. 94.

85 J. Zambrowicz, Imię Chopina, muzyka-rewolucjonisty i jego twórczość jest symbolem przyjaźni narodów radzieckiego i polskiego, „Życie Warszawy” 1949, $\mathrm{nr} 288$, s. 1.

86 Tamże, s. 90.

87 W. Sokorski, dz. cyt., s. 11.

88 Spolszczoną pisownię nazwiska "Szopen” stosowano także przed wojną - choć z nieco innych powodów. Można przypuszczać, że powojenną falę spolszczania nazwiska twórcy w duchu socrealistycznym zapoczątkowała Zofia Lissa wydaną w Moskwie w 1944 roku broszurą Fryderyk Szopen.

89 Rok Chopinowski w 1949 w Polsce, dz. cyt., s. 5. 
trzeba było wielkiego przewrotu rewolucyjnego, trzeba było obalenia monopolu politycznego i kulturalnego klas posiadających, by wielcy twórcy kultury narodowej stali się własnością całego narodu, a nie garstki klas posiadających ${ }^{90}$.

Z przeprowadzonej dotychczas analizy wynika, że moderując chopinowski dyskurs, władza ludowa próbowała zakorzeniać poszczególne jego elementy w historii, zwłaszcza w biografii twórcy. W kontekście wątku walki klas warto wspomnieć o tych ustępach z broszury Zofii Lissy Fryderyk Szopen, w których autorka posądzała polskie kręgi arystokratyczne na emigracji o zapomnienie Chopina w godzinie jego śmierci ${ }^{91}$. W podobnym tonie pisała o pobycie kompozytora w Wiedniu, gdzie Chopin miał czuć się źle „w atmosferze sytych i zadowolonych mieszczuchów"92. Z kolei rosyjski muzykolog, teoretyk muzyki i kompozytor Boris Asafiew posunął się do przytoczenia rzekomego ustępu z listu kompozytora: „klasy burżuazyjne potrzebują czegoś zadziwiającego, mechanicznego, do czego ja nie jestem zdolny"93.

Zagadnienie walki klas stało się także jednym z głównych wątków socrealistycznej narracji Konkursu Chopinowskiego. W jednym z doniesień prasowych czytamy:

W salach koncertowych wiele zmieniło się od czasów przedwojennych: zamiast bogatych snobów i zamożnego mieszczaństwa, które przeważało wśród przedwojennych bywalców sal koncertowych [...], widzimy ludzi pracy. Jest wśród nich wielu robotników i urzędników, w ciżbie ludzkiej często migają czapki uczniowskie i studenckie ${ }^{94}$.

Walka klas stanowi również jeden z narracyjnych kluczy w filmie Aleksandra Forda. Liczne sceny w Młodości Chopina miały utwierdzać widza w przekonaniu, że szlachcie polskiej zależało przede wszystkim na zniewoleniu chłopa. Sam Chopin w filmie Forda często rozmawia o polityce i żywo się nią interesuje. Warto przywołać tu scenę spotkania z przyjaciółmi, gdy kompozytor oznajmia, że od bogato zinstrumentowanej muzyki Ignacego Feliksa Dobrzyńskiego woli „prostą piosnkę

90 AAN, MKiS, sygn. 742, Przemówienie Premiera Cyrankiewicza..., dz. cyt., k. 64.

91 Z. Lissa, Fryderyk Szopen, dz. cyt., s. 29.

92 Tamże, s. 17.

93 B. Asafiew, Mazurki Chopina, „Sowietskaja Muzyka” 1947, nr 3; cyt. za: Fryderyk Chopin w oczach Rosjan, dz. cyt., s. 305.

94 Migawki z Romy. Konkurs Chopinowski trwa, „Polska Zbrojna” 1949, nr 283, s. 5. 
Zuzki”, swojej gosposi. Wraz z przyjaciółmi demonstracyjnie odśpiewuje ową "piosnkę" w kawiarni wypełnionej po brzegi artystokratami (prawdopodobnie w Honoratce przy ul. Miodowej w Warszawie). Wywołuje tym oburzenie snobistycznej arystokracji, co z kolei rozpoczyna żywą dyskusję. Gdy z ust jednego z arcykonserwatywnych profesorów pada zarzut, że Mickiewicz, podobnie jak Chopin, „kleci dla kucharek”, profesor Lelewel odpowiada: „A może właśnie dla narodu, który się z gminu podźwiga?". Nie trzeba dodawać, że ta oraz liczne inne wypowiedzi narzucają odbiorcy dość nachalne skojarzenia z marksistowskim dyskursem i doktryną realnego socjalizmu w kulturze.

\section{Chopin - rewolucjonista}

W jednym z przemówień Bolesław Bierut stwierdził, że „artysta powinien być wychowawcą, jednocząc w sobie socjalizm $\mathrm{z}$ rewolucyjnym romantyzmem” 95 . „Patos wielkiej epoki, patos pracy i walki, heroizm ludu radzieckiego, jasne spojrzenie w przyszłość, a więc właśnie rewolucyjny romantyzm"96 stanowiły w myśl doktryny realizmu socjalistycznego nieodzowny element wszelkich dzieł sztuki. „Rewolucyjny romantyzm” miał „podnosić ludzi na duchu, porywać ich wciąż do nowych wielkich i bohaterskich czynów, pomagać im budować szczęście"97. Z jednej strony wpisywanie Chopina w kontekst rewolucyjnej sztuki romantycznej nie było niczym niezwykłym. Z drugiej jednak przedstawienie go jako rewolucjonistę i proroka socjalizmu było zadaniem odważnym i trudnym.

Jerzy Broszkiewicz przesycił pełną patosu narrację Opowieści o Chopinie polityką, bitwami i rewolucjami, nadając swemu dziełu walor parenetyczny ${ }^{98}$. Wykorzystując batalistyczną metaforykę oraz eksponując odpowiednie tło historyczne, autor umieścił postać kompozytora w centrum wiru rewolucyjnych wydarzeń.

Zdawać by się mogło, że z kompozytora o tak delikatnej fizjonomii i wątłym zdrowiu jak Chopin trudno uczynić bojownika-rewolucjonistę.

95 Cyt. za: B. Wolny, O realizmie socjalistycznym, „Po Prostu” 1949, nr 22, s. 5.

96 Tamże.

97 Tamże.

98 J. Broszkiewicz, dz. cyt., s. 16. 
Tym bardziej interesujące okazują się chwyty zastosowane przez Forda w Młodości Chopina. W jednej ze scen młodego geniusza niesie tłum, podczas gdy w tle rozbrzmiewa Etiuda "Rewolucyjna”. Równie czytelnym symbolem jest przeplatanie muzyki Chopina z rewolucyjną pieśnią - Marsylianką. W innej scenie ostatnie trzy nuty Preludium d-moll op. 28 przechodzą bezpośrednio w huk armat powstania listopadowego. W ten sposób z muzyki Chopina rodzi się rewolucja.

W sztuce realizmu socjalistycznego „wolny od przesądów twórca” musiał przede wszystkim „zdać sobie sprawę, że podstawowym źródłem jego twórczości jest ciężka praca robotnika i chłopa"99. Obowiązkiem artysty było „wczuć się w tętno pracy mas ludowych, w ich tęsknotę i potrzeby, z ich wzruszeń i przeżyć czerpać natchnienie twórcze do własnego wysiłku, którego głównym i podstawowym celem winno być podniesienie i uszlachetnienie poziomu życia tych mas" 100. Wpisując Chopina w ramy socrealistycznej poetyki, twórcy „zaangażowani" musieli uczynić z niego wzór rewolucyjnego wychowawcy narodu i proroka. Często zabiegi te wymagały naginania prawdy historycznej, a mówiąc dosadniej: historycznych fałszerstw. Za przykład posłużyć może artykuł Jerzego Jasieńskiego, który na łamach „Trybuny Ludu” przedstawił Chopina jako „proroka zapowiadającego nadejście zwycięskiej epoki rewolucyjnego socjalizmu”101. W podobnym tonie wypowiadał się również Cyrankiewicz: „Twórczość Chopina [...] była wyrazem gromadzących się sił protestu, zapowiedzią zwycięstwa w przyszłości. Dziś realizuje się ta zapowiedź dawnych wolnościowych manifestów” 102 . Dość toporne hasła związane z „rewolucyjnością” Chopina pojawiały się również w nagłówkach artykułów prasowych. Warto przytoczyć ten, który opublikowany został w „Życiu Warszawy”: Imię Chopina, muzyka-rewolucjonisty i jego twórczość jest symbolem przyjaźni narodów radzieckiego i polskiego ${ }^{103}$.

99 Z przemówienia Prezydenta Rzeczypospolitej Bolesława Bieruta..., dz. cyt., s. 3-4. 100 Tamże.

101 J. Jasieński, „Nie mówit: naród - ale - był nim cały”, „Trybuna Ludu” 1949, nr 285, s. 6.

102 AAN, MKiS, sygn. 742, Przemówienie Premiera Cyrankiewicza..., dz. cyt., k. 64. 103 J. Zambrowicz, dz. cyt., s. 1. 


\section{Chopin pod strzechą, w świetlicy i z fabryką w tle}

Sztandarowym hasłem realizmu socjalistycznego było „upowszechnianie"104. Doktryna wskazywała, że kultura ma dotrzeć do szerokich mas społeczeństwa, do każdego prostego człowieka; sztuka powinna wyrwać się z okowów intelektualnego, burżuazyjnego zamknięcia i wkroczyć na arenę prawdziwego życia robotnika. Niezwykle ważnym miejscem w pejzażu socjalistycznej kultury była świetlica. Miała stanowić podstawowy ośrodek socjalistycznego wychowania mas. Wokół niej koncentrować się miało życie kulturalne, towarzyskie i intelektualne robotnika, to tam miała wychodzić mu naprzeciw „humanistyczna” sztuka. W jednej z notatek Wydziału Kultury KC PZPR z początku 1950 roku ilość świetlic szacowana jest na dziewięć tysięcy ${ }^{105}$. We wszystkich klubach robotniczych i świetlicach wygłaszane były „referaty i prelekcje poświęcone życiu i twórczości Chopina"106. Wartościowym kompendium dla świetlic wydanym z okazji jubileuszu była kilkukrotnie już przywoływana broszura Zofii Lissy Chopin. Materiały do użytku świetlic. Publikacja ta miała

służyć kultowi Chopina na trzech różnych drogach. Pierwsza z nich to zapoznanie czytelników w sposób najprostszy i najbardziej popularny z postacią Chopina, jego życiem i twórczością. Druga ma na celu ułatwienie urządzania świetlicowych czy szkolnych audycji chopinowskich. Trzecia zaś podaje wskazówki do urządzania wystaw chopinowskich przy pomocy dwóch serii pocztówek (wydanych przez Intytut Fryderyka Chopina) z objaśnieniami ${ }^{107}$.

Choć niewolna od ładunku ideologicznego, książeczka Lissy była dziełkiem bardzo wartościowym i - jak można przypuszczać - niezwykle użytecznym.

W jubileuszowym roku 1949 szczególne miejsce w akcji upowszechniania kultury wśród mas zająć miała oczywiście twórczość Chopina. „Jednym z podstawowych celów [działalności Ministerstwa Kultury

104 Więcej o upowszechnianiu kultury w kontekście Roku Chopinowskiego: AAN, MKiS, sygn. 740, Instytut Fryderyka Chopina, k. 82. Szczegółowy plan pracy i program działalności „upowszechniającej”: tamże, k. 10-11.

105 AAN, KC PZPR, 237/XVIII/17, k. 3.

106 Twórczość Chopina - sztandarem polskiego ducha wolnościowego, „Życie Warszawy" 1949, nr 286, s. 1.

107 Z. Lissa, Chopin. Materiały..., dz. cyt., s. 7. 
i Sztuki oraz Komitetu Wykonawczego Roku Chopinowskiego] było zapoznanie szerokich mas społeczeństwa polskiego z życiem i twórczością Fryderyka Chopina"108. Na wsiach grywano koncerty chopinowskie "na ciężarówkach z pianinami” artyści udawali się „w najdalsze zakątki, tam, gdzie dotychczas nie dotarła muzyka Szopena"109. Ważnym elementem „upowszechniania” była także akcja „Audycje chopinowskie we wszystkich szkołach RP" organizowana przez Ministerstwo Kultury i Sztuki ${ }^{110}$. Przy okazji jubileuszu padło wiele szczytnych postulatów, na przykład: „Nie będzie więcej nieszczęśliwych Janków muzykantów każde utalentowane dziecko ma prawo do rozwijania swojego talentu [...]. Każdy artysta może liczyć na opiekę ze strony społeczeństwa"111. Niektóre z owych - do pewnego stopnia słusznych i wciąż aktualnych haseł pobrzmiewają w mentalności polskich środowisk artystycznych po dziś dzień.

Z okazji Roku Chopinowskiego organizowano także liczne wycieczki do Szafarni i do Żelazowej Woli, także dla uczestników Konkursu: „Gości Konkursu, jurorów i uczestników zawieziono na miejsce specjalnymi autokarami. W Szafarni zorganizowano przy tej okazji doroczną imprezę "Chopinowska wieś»" 112 .

Ważnym elementem socjalistycznej gospodarki był przemysł ciężki. Źródła pokazują, że jubileusz stulecia śmierci Chopina był dla władzy wyśmienitą okazją do promowania sukcesów odbudowy oraz osiągnięć właśnie na polu przemysłu. Do demonstrowania postępu i sukcesów gospodarczych służyły władzy ludowej m.in. wycieczki organizowane przez Komitet Wykonawczy Roku Chopinowskiego. Biuro Komitetu przygotowało - wśród wielu innych atrakcji - wycieczkę dla jury Konkursu Chopinowskiego i kandydatów; jej celem było „zaznajomienie uczestników z pięknem historycznej architektury polskiej oraz z rozbudową przemysłu, głównie na Ziemiach Odzyskanych"113.

108 Zob. Rok Chopinowski w 1949 w Polsce..., dz. cyt., s. 23.

109 W komitecie Roku Szopenowskiego..., dz. cyt., s. 3.

110 AAN, MKiS, sygn. 747, Rok Chopinowski 1949. Uchwaty, zarządzenia, regulaminy, k. 40.

111 IV Międzynarodowy Konkurs Chopinowski. Po drugim etapie, „Życie Warszawy” 1949, nr 277, s. 3.

112 Por. W. Sierdakowski, Reportaż z wycieczki do Szafarni, „Rzeczpospolita” 1949, nr 268, s. 4.

113 AAN, MKiS, sygn. 742, Departament Twórczości Artystycznej, Wydział Twórczości Muzycznej, k. 41. Wyróżnienie pochodzi od autora artykułu. 
Obok Krakowa na mapie wycieczki znalazły się m.in. Katowice, Jelenia Góra czy Dolny Śląsk. W dominujących nurtach narracji podkreślano, że rocznica chopinowska przypada w okresie, gdy „praca robotnika i chłopa zmienia ruiny w słoneczne domy i tętniące twórczym rytmem fabryki - ugory zaś w żyzne pola"114.

\section{Międzynarodowy Konkurs Pianistyczny im. Fryderyka Chopina}

Kluczowym wydarzeniem Roku Chopinowskiego był IV Międzynarodowy Konkurs Pianistyczny im. Fryderyka Chopina, który także wykorzystywany był przez socrealistycznych narratorów na potrzeby ideologii. Pierwszym z wątków snutej przez władzę ludową opowieści o Konkursie było eksponowanie na różnych płaszczyznach społecznego egalitaryzmu. Wszak „Konkurs Chopinowski stał się wydarzeniem dnia, żywo obchodzącym ogół ludzi pracy"115. Na kartach jednego z numerów „Życia Warszawy” znaleźć można podobną wypowiedź: „Każdy obserwator mógł z łatwością dostrzec ogromne, narastające z każdym dniem zainteresowanie konkursem wśród społeczeństwa polskiego [...]. Jeżeli chodzi o wzbudzenie zainteresowania dla muzyki Chopina, konkurs zrobił bardzo wiele"116. Pozwolę sobie jednak na moment wrócić do etapu przygotowań. Ich ukoronowaniem w przypadku polskiej ekipy był kilkutygodniowy pobyt w Lagowie Lubuskim latem 1949 roku na "«obozie kondycyjnym», gdzie pod kierunkiem pedagogów, poddając się cotygodniowym "przesłuchaniom» przed znaną nam Komisją, dopracowywano szczegóły programu"117. Ów obóz szkoleniowy pokrywał się w czasie ze sławetnym Zjazdem Kompozytorów Polskich (5-8 sierpnia 1949 roku), w trakcie którego sprecyzowano założenia realizmu socjalistycznego w muzyce i próbowano ustalić plan przebiegu procesu ich adaptacji na polskim gruncie. W Łagowie Lubuskim zbiegły się zatem drogi pianistyki i ideologii.

114 Żywe wydanie dzieł Fryderyka Chopina..., dz. cyt., s. 6.

115 Migawki z Romy..., dz. cyt., s. 4.

116 IV Konkurs Chopinowski zakończony. Zdumiewajaca dojrzałość młodzieży. Świetne wyniki Polaków, „Życie Warszawy” 1949, nr 287, s. 1.

117 Cytat zaczerpnięty z niepublikowanych wspomnień prof. Reginy Smendzianki zarejestrowanych przez Barbarę Niewiarowską we wrześniu 1999 roku. 
Uroczyste otwarcie Konkursu pod protektoratem prezydenta Bolesława Bieruta miało miejsce 18 września. W loży honorowej zasiedli członkowie Rady Państwa z marszałkiem sejmu Władysławem Kowalskim oraz premierem Józefem Cyrankiewiczem na czele. Otwarcia Konkursu dokonał wiceminister kultury i sztuki Włodzimierz Sokorski. Od początku faworytami byli pianiści z Polski i Związku Radzieckiego. Władza ludowa nie mogła nie wykorzystać tego faktu w celach propagandowych. Prasę wypełniły więc depesze, w których podkreślano, że „narodowy polski charakter muzyki Chopina jest siłą rzeczy najbliższy pianistom polskim oraz pianistom bratniego Związku Radzieckiego, gdzie istniał zawsze bardzo żywy i głęboki kult Chopina"118. W gronie laureatów znaleźli się wyłącznie Polacy i obywatele Związku Radzieckiego. Wygrały ex aequo Bella Dawidowicz i Halina Czerny-Stefańska. Nie ma podstaw, aby podważać werdykt jury, niemniej jednak fakt ten z perspektywy działań propagandowych władzy ludowej pozostaje niezwykle wymowny. Premier Józef Cyrankiewicz w przemówieniu wieńczącym Konkurs stwierdził: „Wyniki cieszą nas tym bardziej, że osiągnięcia naszych młodych artystów są w dużym stopniu wynikiem opieki Państwa Ludowego nad rozwojem kultury we wszystkich jego przejawach"119. Także w prasie znaleźć można ustępy, których autorzy przekonywali odbiorców, że „w ludowym ustroju demokratycznym na pewno [laureaci Konkursu Chopinowskiego] znajdą jak najlepsze warunki, najtroskliwszą opiekę i pomoc"120. Nie zapominano także o pozostałych modelowych aspektach narracji, takich jak ludowość ${ }^{121}$.

\section{Wystawa Chopinowska w Muzeum Narodowym}

Niezwykle ważnym akcentem obchodów setnej rocznicy śmierci Chopina była Wystawa Chopinowska zorganizowana w Muzeum Narodowym. Otwarcia Wystawy 19 października 1949 roku dokonał premier Józef Cyrankiewicz. Na wernisażu przemawiali także minister

118 P. Beylin, Konkurs Chopinowski trwa, „Po Prostu” 1949, nr 28, s. 4.

119 AAN, MKiS, sygn. 742, Departament Twórczości Artystycznej, Wydział Twórczości Muzycznej, k. 64.

120 IV Konkurs Chopinowski zakończony..., dz. cyt., s. 4.

121 W. Żuławski, Konkurs Chopinowski, wspaniała impreza kulturalna, „Express Wieczorny" 1949, nr 261. 
Sokorski oraz dyrektor Muzeum Narodowego Stanisław Lorentz ${ }^{122}$. Eksponaty chopinowskie prezentowano, według scenariusza Stefana Jarocińskiego, w pięciu kategoriach: Chopin jako człowiek i twórca, ludowe i patriotyczne źródła twórczości Chopina, kult Chopina w Polsce dziejowej, sto lat dziejów muzyki i idei Chopinowskiej oraz muzyka Chopina jako symbol pokojowej pracy narodów. Całą wystawę podzielono na trzy działy: Epoka Chopina, Ubiegłe stulecie oraz Muzyka Chopina dociera do mas ${ }^{123}$. Szczególnie interesujący z perspektywy niniejszego eseju jest dział trzeci, w którym widz mógł się zapoznać $\mathrm{z}$,akcją umasowienia muzyki Chopina, która wyszedłszy od ludu, dzisiaj stała się własnością szerokich mas narodu polskiego"124.

Obok „wzruszających pamiątek”, jak listy i rękopisy kompozytora, na wystawie można było zobaczyć „fotografie robotników i chłopów, do których dziś dopiero dotarła twórczość Szopena". Autor cytowanego artykułu zwraca uwagę, że „włożyli oni wiele trudu w to, by Nowa Polska mogła starannie wykształcić młodych pianistów, uczestników dzisiejszego Konkursu"125. Dokonując ledwie pobieżnej analizy segmentów wystawy, można zauważyć, jak ważnym dla władzy ludowej elementem były treści służebne wobec ideologii w narracji osoby i twórczości Chopina.

Wątek wystawy intensywnie wykorzystywano w socrealistycznej narracji Roku Chopinowskiego. W artykułach opisujących i recenzujących to wydarzenie kulturalne znaleźć można topiczne stwierdzenia: „Rok Szopenowski w Polsce - to piękny symbol budzącej się kultury socjalizmu"126. W narracji Polskiej Kroniki Filmowej szczególnie wyraźnie w kontekście wystawy zaakcentowany został wątek rewolucyjny. Krótki, dwuminutowy materiał wykorzystuje przytłaczający wręcz ładunek symboliki rewolucyjnej, odwołując się do tak słynnych dzieł jak obraz Eugène’a Delacroix Wolność wiodąca lud na barykady czy Etiuda c-moll „Rewolucyjna” op. 10. Przywołane zostały także opisane wcześniej toposy: Chopina-rewolucjonisty i przyjaciela ludu, walki klas oraz pokojowej współpracy narodów.

\footnotetext{
122 AAN, MKiS, sygn. 742, Departament Twórczości Artystycznej, Wydział Twórczości Muzycznej. Konkurs Chopinowski, biuletyn informacyjny Konkursu, k. 31.

123 Tamże.

124 Tamże.

125 P. Beylin, Międzynarodowy Konkurs Szopenowski, „Po Prostu” 1949, nr 25, s. 7. 126 Tamże.
} 


\section{Chopin w poezji socrealistycznej}

Interesującym wątkiem w podróży śladami socrealistycznej narracji chopinowskiej jest badanie poezji. W pracy tej nie ma wprawdzie miejsca na szczegółowe analizy poszczególnych wierszy, pozwoliłem sobie jednak zaznaczyć wszystkie sformułowania, które według mnie budzą oczywiste skojarzenia z socrealistyczną poetyką, pozostawiając je estetycznej ocenie czytelnika.

W wierszu Chopin Witolda Wirpszy, podczas zebrania przedwyborczego Frontu Narodowego „w świetlicy dochodzi do rewolucji”"127. Na starym, zakurzonym, obdrapanym pianinie stojącym w kącie gra kobieta. Dźwięk przypomina podmiotowi lirycznemu cymbały - a zatem instrument ludowy. Można odczytać to jako subtelne nawiązanie do omawianego już we wcześniejszych fragmentach ludowego charakteru twórczości Chopina. W innym miejscu podmiot liryczny podsuwa czytelnikowi metaforykę industrialną: wydobywany z instrumentu dźwięk „runął na słuchaczy jak ulewa stali”. Stal symbolizuje odbudowę, nowoczesność, solidność; zastosowanie tego typu przenośni może podsuwać odbiorcy skojarzenia z poetyką realizmu socjalistycznego. W kolejnych strofach następuje dalsze spiętrzenie przemysłowo-militarnej metaforyki: pojawia się symbol Rewolucji Październikowej krążownik Aurora, a także lufy, kominy, dźwigi, beton, zapory, piece. Według podmiotu lirycznego z muzyki polskiego kompozytora wyłania się wizja szturmującego tryumfalnie wojska i spływającej pod czerwonym sztandarem stali z pieców hutniczych. W końcu „padł z hukiem ostatni akord” $i$ „rewolucyjna cisza zapada w świetlicy”. Podmiot liryczny sugeruje, że muzyka Chopina napełniła zebranych tam ludzi pozytywnymi emocjami - tak jak powinna czynić sztuka realizmu socjalistycznego. Podobny typ metaforyki wykorzystał Ludwik Goliński w wierszu Wierzba nad Chopinem, gdzie podmiot liryczny wspomina m.in. o „wierzbie złamanej czołgiem”"128. Włodzimierz Słobodnik w wierszu Ku czci Chopina „ogrywa” z kolei „topos ludowy”, pisząc o „czerstwej pieśni wieśniaczek”, którą „podniósł z ziemi Chopin” ${ }^{129}$.

127 W. Wirpsza, Chopin, [w:] Wiersze o Chopinie. Antologia i bibliografia, red. E. Słuszkiewicz, Kraków 1964.

128 L. Goliński, Wierzba nad Chopinem, [w:] Wiersze o Chopinie..., dz. cyt., s. 148.

129 W. Słobodnik, Ku czci Chopina, [w:] Fryderyk Chopin natchnieniem poetów. W setna rocznicę śmierci, red. K. Kobylańska, Warszawa 1949, s. 141. 
Interesująca metafora muzyczna pojawia się w wierszu Heleny Platty zatytułowanym Chopin. Podmiot liryczny, zwracając się do kompozytora, mówi o „wszystkich rękach”, które „pochwycą za młoty i zaczną kuć preludium, zaś na najwyższym tonie znów stanie kiedyś samotny pomnik"130.

W socrealistycznej poezji przewijały się niemal wszystkie analizowane przeze mnie wcześniej wątki, szczególnie „rewolucyjny”, militarny i przemysłowy. Muzyka genialnego kompozytora stanowiła także często tło dla wydarzeń zagłady. Twórczość Chopina stawała się w poezji realizmu socjalistycznego zwiastunem przyszłych przemian rewolucyjnych.

\section{Zakończenie}

Władza ludowa w Polsce miała przemożny wpływ na prowadzenie i moderowanie narracji Roku Chopinowskiego we wszystkich oficjalnych źródłach. Wpisywała lub skłaniała do wpisywania twórczości i osoby Fryderyka Chopina w socrealistyczny kontekst za pomocą kilku modyfikowanych na rozmaite sposoby schematów.

W narracji eksponowano zgodny z doktryną realizmu socjalistycznego „głęboki humanizm muzyki Chopina” oraz jej ludowe pierwowzory, które urastały do rangi źródeł jedynych. Wśród chopinowskich gatunków prym wiódł mazurek; inne formy, które nie niosły ze sobą ludowych konotacji (np. ballady, scherza, sonaty), były w dyskursie marginalizowane. Polski kompozytor, przedstawiony w socrealistycznych narracjach jako rewolucjonista i prorok zwycięstwa socjalizmu, łączyć miał „braterskie narody” Polaków i Rosjan. Nie darzył natomiast sympatią ani Niemców, ani niemieckiej kultury, z której narodzić miały się później potworności hitleryzmu. Władzy zależało na tym, aby Chopin trafił w ramach wielkiej akcji „upowszechnieniowej” do prostego ludu: pod strzechy i do świetlic. Aspekt upowszechniania łączony był często z zagadnieniem walki klas, które także wyraźnie objawia się w kontekście socrealistycznej narracji Roku Chopinowskiego.

Rok Chopinowski zbiegł się z apogeum socrealistycznej ofensywy na polu kultury, przez co przerodził się w wielką, ideologiczną akcję propagandową. Działania władzy ludowej rozgrywały się przede wszystkim na polu recepcji oraz kształtowania pamięci polskiego kompozytora. Były natomiast oddalone od muzyki per se, mimo że w służbie ideologii tak silnie wykorzystywano chociażby Konkurs Chopinowski.

130 H. Platta, Chopin, [w:] Fryderyk Chopin natchnieniem..., dz. cyt., s. 150. 
Należy zaznaczyć, że w tym okresie ukazywały się również publikacje niezideologizowane. Należą one jednak do zdecydowanej mniejszości. Były to przede wszystkim analizy muzykologiczne ${ }^{131}$, dostępne wąskiej grupie osób, które nie miały zbyt dużego wpływu na zbiorową pamięć społeczną. A jednak, choć nie na wszystkich źródłach odciśnięte zostało piętno doktryny, często ideologiczne zadanie spełniał sam kontekst. Nawet jeśli otwierając 273. numer "Trybuny Ludu” z 1949 roku odbiorca natknął się na artykuł, w którym Chopin nie był ukazany jako rewolucjonista powiązany nicią braterstwa $\mathrm{z}$ sąsiadami ze Wschodu na tle fabryk i polskiego ludu, to w jego sąsiedztwie odnajdywał takie teksty jak: Każdy dzień naszego życia oddamy walce o socjalizm i pokój, Niech żyje wiecznie i krzepnie przyjaźn narodów Polski i ZSRR, Miejsce inteligencji polskiej jest u boku klasy robotniczej czy Imperializm amerykański - dziedzic hitleryzmu.

Władza ludowa w Polsce w 1949 roku miała na celu budowanie wśród społeczeństwa poczucia wspólnoty. Chopin, podobnie jak Mickiewicz, Słowacki czy Norwid, wykorzystywany był jako sztandar, pod którym miało nastąpić zjednoczenie i konsolidacja robotniczej kultury realizmu socjalistycznego.

\section{Bibliografia}

\section{Źródła}

Prasa

„Ekspres Wieczorny” 1949; „Kurier Codzienny” 1949; „Kwartalnik Muzyczny” 1948-1949; „,Muzyka” 1950-1951; „Poland of Today” 1949; „Polska Zbrojna” 1949; „Przekrój” 1949; „Ruch Muzyczny” 1949; „Śpiewak” 1948; „Trybuna Ludu” 1949; „Życie Śpiewacze” 1949; „Życie Warszawy” 1949.

Capenko M., Realizm socjalistyczny. Metoda budownictwa radzieckiego, „Stolica” 1950, nr 20.

Dołgopołow M., Szopenowskij god w Polsze, „Sowietskaja Muzyka” 1949, nr 5.

131 Zob. M. Mirska, Szlakiem Chopina, Warszawa 1949; W. Paschałow, Chopin a polska muzyka ludowa, Kraków 1951; Z. Jachimecki, Chopin. Rys życia i twórczości, Warszawa 1949. 
Hordyński W., Chopin u sasiadów - Związek Radziecki - Ludzie radzieccy czcza pamięć wielkiego polskiego kompozytora, „Odra” 1949, nr 5. Idzikowski M., Kult Fryderyka Chopina, „Płomień” 1949, nr 4.

Kabalewski D., Chopin u sąsiadów - Związek Radziecki - Przyjaciel, „Odra” 1949, nr 45.

Kisielewski S., Chopin, „Tygodnik Powszechny” 1949, nr 8.

Kisielewski S., Czy muzyka jest niehumanistyczna, „Znak” 1948, nr 8.

Lissa Z., Ideologiczne oblicze polskiej twórczości muzycznej, „Nowe Drogi" $1948, \mathrm{nr} 7$.

Łobaczewska S., Jeden z celów Konkursu Chopinowskiego, „Dziennik Literacki” 1949, nr 39.

Mycielski Z., Twórcy a masy, „Nowiny Literackie” 1948, nr 4.

Obchody „Roku Chopinowskiego”, „Poradnik Muzyczny” 1948, nr 5.

Rudziński W., Dlaczego Konkurs Chopinowski wypadł dla nas tak korzystnie, „Odrodzenie” 1949, $\mathrm{nr} 3$.

Stulecie śmierci Chopina w ZSRR, „Przyjaźń” 1949, nr 43.

Z przemówienia Prezydenta Rzeczypospolitej Bolesława Bieruta na otwarciu radiostacji we Wrocławiu $w$ dniu 16 listopada 1947 roku, „Przegląd Artystyczny. Pismo Związku Polskich Artystów Plastyków” 1950, $\mathrm{nr} 1 / 2$.

\section{Druki zwarte}

Broniewski W., Mazurek Szopena, [w:] tenże, Bagnet na broń, Warszawa 1946.

Broszkiewicz J., Opowieść o Chopinie, Warszawa 1950.

Filip T., Cypriana Norwida „Fortepian Szopena” ze stanowiska twórczości poety odczytany, Kraków 1949.

Idzikowski M., Rok Chopinowski 1949 w programie Instytutu Fryderyka Chopina, Warszawa 1947.

Fryderyk Chopin w oczach Rosjan, red. G. Wiśniewski, Warszawa 2010. Iwaszkiewicz J., Chopin, Warszawa 1949.

Jachimecki Z., Chopin. Rys życia i twórczości, Warszawa 1949.

Kobylańska K., Fryderyk Chopin natchnieniem poetów. W setna rocznice śmierci, Warszawa 1949. 
Korespondencja Fryderyka Chopina, oprac. B. Sydow, t. 1-2, Warszawa 1955.

Korespondencja Fryderyka Chopina, t. 1, 1816-1831, oprac. Z. Helman, Z. Skowron, H, Wróblewska-Straus, Warszawa 2009.

Kultura muzyczna Polski Ludowej 1944-1955, red. J. Chomiński, Z. Lissa, Kraków 1957.

Międzynarodowe Konkursy Pianistyczne im. Fryderyka Chopina, red. K. Czekaj, Warszawa 1954.

Mirska M., Szlakiem Chopina, Warszawa 1949.

Lissa Z., Chopin. Materiały do użytku świetlic, Warszawa 1949.

Lissa Z., Fryderyk Szopen. Krótki życiorys, Moskwa 1944.

Lissa Z., Niektóre zagadnienia estetyki muzycznej w świetle artykułów Józefa Stalina o marksizmie w językoznawstwie, Kraków 1952.

Lissa Z., Problemy stylu narodowego muzyki Chopina, Warszawa 1955. Lissa Z., Uwagi o metodzie marksistowskiej w muzykologii, Kraków 1950. Paschałow W., Chopin a polska muzyka ludowa, Kraków 1951.

Rok Chopinowski 1949 w Polsce, red. Komitet Wykonawczy Roku Chopinowskiego 1949, Warszawa 1949.

Skowrońska J., Mały Chopin. Inscenizowane opowieści z cyklu „Teatr dzieci z podwórka", Warszawa 1949.

Słobodnik W., Szopen, [w:] tenże, Wiersze zebrane, Warszawa 1948.

Słuszkiewicz E., Wiersze o Chopinie. Antologia $i$ bibliografia, Kraków 1964.

Sokorski W., Sztuka w walce o socjalizm, Kraków 1950.

Stromenger K., Fryderyk Chopin. W stulecie śmierci, Warszawa 1949. Żywe wydanie dzieł Fryderyka Chopina. Program czternastu koncertów obejmujacych cała twórczość Fryderyka Chopina, red. Komitet Wykonawczy Roku Chopinowskiego 1949, Warszawa 1949.

Film

Młodość Chopina, reż. A. Ford, 1951.

Polska Kronika Filmowa, 1949. 
Archiwalia

\section{Archiwum Akt Nowych (AAN)}

KC PZPR 237/XVIII/16, KC PZPR, 237/XVIII/17, KC PZPR, 237/XVIII/74, KC PZPR, 237/XVIII/75, KC PZPR, 237/XVIII/76, KC PZPR, 237/ XVIII/77, Komitet Centralny Polskiej Zjednoczonej Partii Robotniczej. Wydział Kultury. Sektor Kulturalno-Oświatowy.

KC PZPR 237/VIII/52-61, Komitet Centralny Polskiej Zjednoczonej Partii Robotniczej. Wydział Propagandy i Agitacji. Sektor Wydawnictw $i$ Wystaw oraz Sektor Propagandy i Agitacji Masowej.

KC PZPR 1354/XXXIV/1-243, Komitet Centralny Polskiej Zjednoczonej Partii Robotniczej. Wydział Pracy Ideowo-Wychowawczej.

MKiS 366/165-314, Ministerstwo Kultury i Sztuki w Warszawie 1945-1976. Departament Muzyki.

MKiS 366/1-76, Ministerstwo Kultury i Sztuki w Warszawie 1945-1976. Zarzadzenia, plany, sprawozdania 1949-1956.

MKiS 366/1-26, Ministerstwo Kultury i Sztuki w Warszawie 1945-1976. Biuro Obchodów Artystycznych: sprawozdania 1949-1953.

MKiS 366/1-271, Ministerstwo Kultury i Sztuki w Warszawie 1945-1976. Zarząd Szkół Artystycznych: szkoły muzyczne, plastyczne, teatralne, baletowe, filmowe 1947-1968.

Biblioteka Związku Kompozytorów Polskich w Warszawie 12/3 oraz 12/4, Protokoły obrad Zjazdów Zwiazku Kompozytorów Polskich 1947-1948.

\section{Opracowania}

Baculewski K., Współczesność. Część 1: 1939-1974, seria «Historia Muzyki Polskiej», red. S. Sutkowski, t. 7, Warszawa 1996.

Banaszak G., Współczesne formy kultury muzycznej, Warszawa 1991. Chopin w kulturze polskiej, red. M. Gołąb, Wrocław 2009.

Chopin - w poszukiwaniu wspólnego języka. Materiały z konferencji, red. A. Szklener, Warszawa 2004.

Ekiert J., Chopin wiecznie poszukiwany. Historia Międzynarodowego Konkursu Pianistycznego im. Fryderyka Chopina w Warszawie, Warszawa 2010. 
Fik M., Kultura polska po Jałcie. Kronika lat 1944-1948, Warszawa 1991. Głowiński M., Rytuał i demagogia, Warszawa 1992.

Golka M., Pamięć społeczna i jej implanty, Warszawa 2009.

Golka M., Socjologia kultury, Warszawa 2007.

Idzikowska-Czubaj A., Rock w PRL-u. O paradoksach wspótistnienia, Poznań 2011.

Kłosiński K., Człowiek w sytuacji kontaktu z muzyka, Warszawa 1995.

Kukurowski S., Nie tylko socrealizm. O tzw. literaturze propagandowej, tendencyjnej i zaangażowanej, Wrocław 2005.

Mazur M., O człowieku tendencyjnym. Obraz nowego człowieka $w$ propagandzie komunistycznej w okresie Polski Ludowej i PRL 1944-1956, Lublin 2009.

Misiak T., Muzyka jako wspólnota. Kulturowe wzory odbioru muzyki w europejskiej kulturze muzycznej XX wieku, Warszawa 1990.

O społecznych problemach muzyki. Antologia tekstów autorów polskich, red. M. Demska-Trębacz, Warszawa 1994.

Pociej B., Polskość Chopina, Warszawa 2011.

Polska współczesna kultura muzyczna 1944-1964, red. E. Dziębowska, Kraków 1967.

Polski socrealizm. Antologia publicystyki społeczno-kulturalnej z lat 1948-1957, red. L. Lachowiecki, T. Markiewicz, M. Paczkowski, Warszawa 1988.

Schütz A., Wspólne tworzenie muzyki. Studium relacji społecznych, [w:] tenże, O wielości światów. Szkice z socjologii fenomenologicznej, tłum. B. Jabłońska, t. 4, Kraków 2008.

Socrealizm? Dyskusja redakcyjna. Michał Bristiger, Andrzej Mencwel, Stefan Morawski, Wojciech Tomasik, Władysław Malinowski, „De Musica” 3 (2002).

Szpociński A., Przeszłość jako przedmiot przekazu, Warszawa 2006.

Śliwińska K., Socrealizm w PRL i NRD, Poznań 2006.

Teoria kultury a badania nad zjawiskami artystycznymi, red. T. Kostyrko, Warszawa 1983.

Tyszka A., Uczestnictwo w kulturze, Warszawa 1971.

Wieczorek S., Na froncie muzyki. Socrealistyczny dyskurs o muzyce $w$ Polsce w latach 1948-1955, Wrocław 2009.

Włodarczyk W., Socrealizm. Sztuka polska w latach 1950-1954, Kraków 1991. 